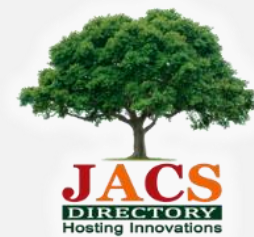

Journal of Nanoscience and Technology

\title{
Studies on $\mathrm{ZrO}_{2}$ Thick and Thin Films: Structural, Morphological, Optical and Microstructure Behaviour
}

\author{
S.B. Deshmukh1,*, S.B. Patil2, R.H. Bari ${ }^{3}$
}

${ }^{1}$ Department of Physics, M.S.G. Arts, Science and Commerce College, Malegaon - 423 105, Maharashtra, India.

${ }^{2}$ Department of Physics, A.R.B. Garud, Arts, Commerce and Science College, Shendurni - 424 204, Maharashtra, India.

${ }^{3}$ Nanomaterials Research Laboratory, Department of Physics, G.D.M. Arts, K.R.N. Commerce and M.D. Science College, Jamner - 424 206, Maharashtra, India.

\section{A R T I C LEDETA I L S}

\section{Article history:}

Received 07 September 2019

Accepted 27 September 2019

Available online 14 October 2019

Keywords:

$\mathrm{ZrO}_{2}$

Thick Films

Analytical Techniques

\section{A B S T R A C T}

In present work we have synthesized $\mathrm{ZrO}_{2}$ thick and thin film by different techniques. Prepared $\mathrm{ZrO}_{2}$ thick and thin films were investigated by different analytical techniques such as XRD, FESEM, FETEM, and UV-Visible spectral studies. From these studies, it was observed that the size of the synthesized films is found within $25 \mathrm{~nm}$ and $7 \mathrm{~nm}$ crystallite sizes for thick and thin film respectively. Crystanality, grain size, band gap, activation energy and other for both films were discussed, interpreted and reported. Comparative studies in all aspects were presented in this work.

\section{Introduction}

$\mathrm{ZrO}_{2}$ has potential as a thermal barrier coating in devices due to its low thermal conductivity [1]. Zirconium oxide possesses the amazing ability to conduct electricity through the migration of oxygen ions $\left(\mathrm{O}^{2-}\right)$ [2]. Therefore, in the present work it is used to fabricate thick film resistor. This property is seen at temperatures above $250{ }^{\circ} \mathrm{C} . \mathrm{ZrO}_{2}$ has been widely used for various applications such as semiconductor in dye- sensitized, solar cell, fuel cell, transparent optical device, optical coatings, solid electrolytes for gas sensors, for medication, and resistive gas sensors [37].

Sensors in the form of thick films are very attractive and have been widely used in gas sensing application. The main advantages of thick film sensors are simple construction, small size, good sensitivity, selectivity, quick response and fast recovery time, low operating temperature, high stability, good accuracy, easy processing, reproducibility, low Cost and low consumption. It is flexible and versatile technology wherein resistors and capacitors of various values, combinations can be fabricated with basic thick film functional materials with desired pattern on substrates [8].

The spray pyrolysis technique has been applied to deposit a wide variety of thin films. These films were used in various devices such as solar cells, sensors, and solid oxide fuel cells. The properties of deposited thin films depend highly on the preparation conditions. An extensive review of the effects of spray parameters on film quality is given to demonstrate the importance of the process parameters $[9,10]$. The substrate surface temperature is the most critical parameter as it influences film roughness, cracking, crystalline, etc. Processes involved in spray pyrolysis technique, such as atomization of the precursor solution, aerosol transport, and decomposition of the precursor are discussed in this review. Only rough models about the mechanism of film formation have been published so far. Many authors have suggested that a modified CVD process occurs close to the substrate. However, many observations contradict the involvement of CVD process during the spray pyrolysis process [11-16].

In the present investigations, $\mathrm{ZrO}_{2}$ thick and thin films were prepared by different method. Structural properties, surface morphology, microstructure property, elemental composition and optical band gap energy were studied using X-ray diffraction, FE-SEM, TEM, EDAX and UVspectroscopy respectively.

\section{Experimental Methods}

\subsection{Preparation of Thick Films}

Zirconium dioxide was prepared by dissolving $25 \mathrm{~g}$ of Zirconyl (IV) chloride octohydrate $\left(\mathrm{ZrOCl}_{2} .8 \mathrm{H}_{2} \mathrm{O}\right)$ [Sigma-Aldrich] in $200 \mathrm{~mL}$ deionized water. The solution was stirred at $98^{\circ} \mathrm{C}$ for $2 \mathrm{~h}$ in which drop wise aqueous ammonia solution was added until a $\mathrm{pH}$ value of 9.3 achieved after with subsequent filtration and washing to obtain $\operatorname{Zr}(\mathrm{OH})_{4}$. This compound was dried at $100{ }^{\circ} \mathrm{C}$ for $24 \mathrm{~h}$, heated at $1{ }^{\circ} \mathrm{C} / \mathrm{min}$ up to $600{ }^{\circ} \mathrm{C}$ and calcinated for $3 \mathrm{~h}$ to produce $\mathrm{ZrO}_{2}$ and it was dried, grinded for formation of small grains and calcinated at $800{ }^{\circ} \mathrm{C}$ in muffle furnace for few hours.

$\mathrm{Zr}(\mathrm{OH})_{4} \stackrel{600^{\circ} \mathrm{C}}{\rightarrow} \mathrm{ZrO}_{2}+2 \mathrm{H}_{2} \mathrm{O} \uparrow$

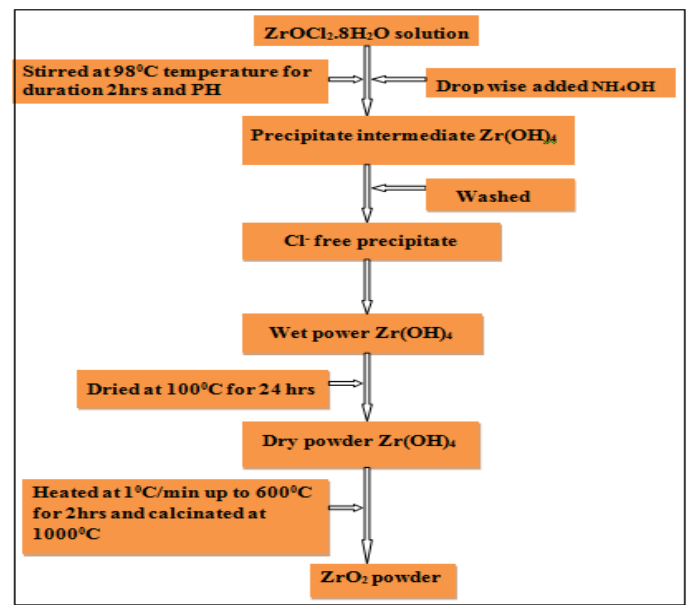

Fig. 1 Flowcharts represent schematic synthesis of $\mathrm{ZrO}_{2}$ powder to prepare thick films

\subsection{Preparation of $\mathrm{ZrO}_{2}$ Thin Film Precursor}

The precursor used in this study was zirconium oxychloide octohydrate $\left(\mathrm{ZrOCl}_{2} .8 \mathrm{H}_{2} \mathrm{O}\right)$. It consists chloride ions and 8 water molecules, therefore most common solvents seemed to be water. $1.6102 \mathrm{~g} \mathrm{ZrOCl}_{2} .8 \mathrm{H}_{2} \mathrm{O}$ was dissolved in $100 \mathrm{~mL}$ double distilled water to produce $0.05 \mathrm{M}$ precursor spraying solution. 


\subsection{Deposition of Nanostructured $\mathrm{ZrO}_{2}$ Thin Films}

As prepared precursor solution of $\mathrm{ZrOCl}_{2} .8 \mathrm{H}_{2} \mathrm{O}(0.05 \mathrm{M})$ was sprayed, through a glass nozzle of $0.1 \mathrm{~mm}$ bore diameter on hot glass substrate at temperature $350 \pm 5^{\circ} \mathrm{C}$ at spray rate $5 \mathrm{~mL} / \mathrm{min}$ for different spray time 30 min and these deposited samples for various deposition time is referred. The horizaonatal movement was kept uniform and compressor air pressure controlled between 3 to $8 \mathrm{~kg} / \mathrm{cm}^{2}$, this had been done to optimized viscosity and surface tension and momentum of the droplet. Also, substrate to nozzle distance played better role and kept as $28 \mathrm{~cm}$.

\section{Results and Discussion}

\subsection{X-Ray Diffraction Study}

Fig. 2 (a-b) shows XRD pattern of thick and thin films respectively. The hkl planes (200) and (222) corresponding to monoclinic phase of $\mathrm{ZrO}_{2}$. The plane (111), (220), (311) and (400) corresponding to tetragonal phase of $\mathrm{ZrO}_{2}$. All the peaks well matched with standard JCPDS data cards 17-0923, 36-020 and 34-1084.
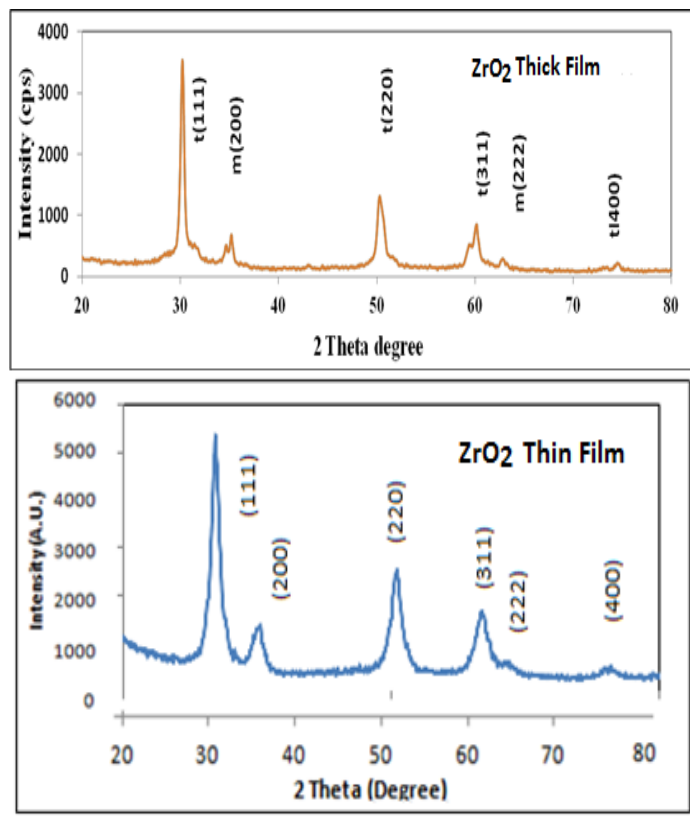

Fig. $2 \mathrm{XRD}$ of $\mathrm{ZrO}_{2}$ for (a) thick films and (b) thin films

The average crystallite size of $\mathrm{ZrO}_{2}$ thick and thin film was determined using Debye- Scherrer's formula,

$$
\mathrm{D}=\frac{0.9 \lambda}{\beta \cos \theta}
$$

where, $D=$ Average crystallite size, $\lambda=X$-ray wavelength $(1.542 \AA), \beta=$ FWHM of the peak in radians and $\theta=$ Diffraction peak position. It was found to be $25 \mathrm{~nm}$ and $7 \mathrm{~nm}$ crystallite sizes for thick and thin film respectively.

\subsection{SEM Images of Surface Morphology}

Fig. 3 (a and b) shows surface morphology of pure $\mathrm{ZrO}_{2}$ thick and thin films. From the images, it is clear that the grains are bulk and nanocrystalline in nature and the grains are found to be spherical in nature and uniformly distributed.

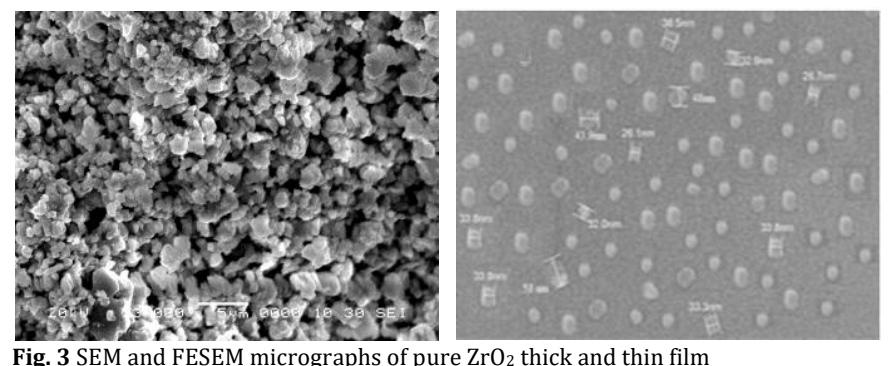

\subsection{Elemental Analysis using EDAX}

The quantitative elemental composition of $\mathrm{Zr}$ and $\mathrm{O}$ associated in thick and thin film sensor element was carried out and shown in Table 1. Atomic https://doi.org/10.30799/jnst.285.19050506 wt.\% of cations ( $\mathrm{Zr}$ ) and anions (O) are 66.45 and 33.55 respectively. It is matched with theoretical expected wt.\% percentage. A nanocrystalline $\mathrm{ZrO}_{2}$ thin film is observed to be nearly stochiometric in nature.

Table 1 Elemental compositional analysis of $\mathrm{ZrO}_{2}$ thick film and $\mathrm{ZrO}_{2}$ thin film

\begin{tabular}{lllll}
\hline Elemental & \multicolumn{2}{l}{ Fired $\mathrm{ZrO}_{2}$ thick films } & \multicolumn{2}{l}{ Annealed $\mathrm{ZrO}_{2}$ thin films } \\
\cline { 2 - 5 } composition & mass $\%$ & at $\%$ & mass $\%$ & at $\%$ \\
\hline $\mathrm{Zr}$ & 74.33 & 66.45 & 71.00 & 33.04 \\
0 & 25.7 & 33.55 & 29.00 & 66.96 \\
$\mathrm{ZrO}_{2}$ & 100 & 100 & 100 & 100 \\
\hline
\end{tabular}

3.4 TEM analysis of Microstructural Property

\subsubsection{Thick Film Analysis}

Microstructural property studies were carried out using TEM as shown in Fig. 4 (a) values were observed using SAED pattern which is shown in Fig. 5.
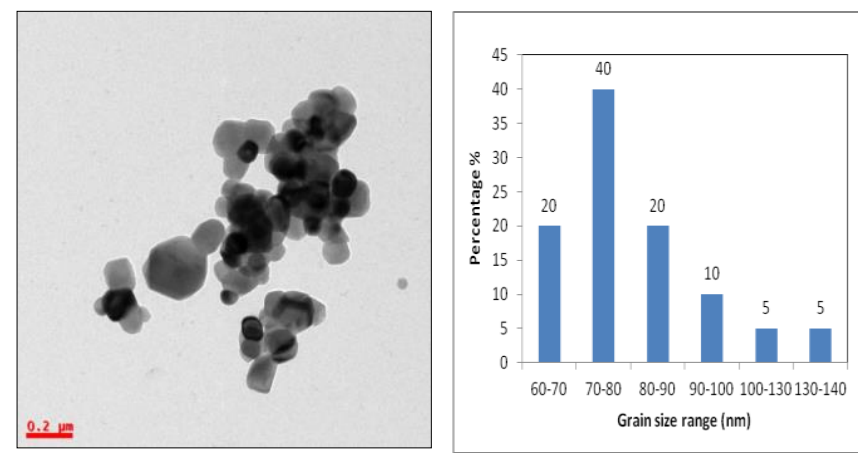

Fig. 4 TEM image of disspersed ZrO thick film sample and grain size histogram

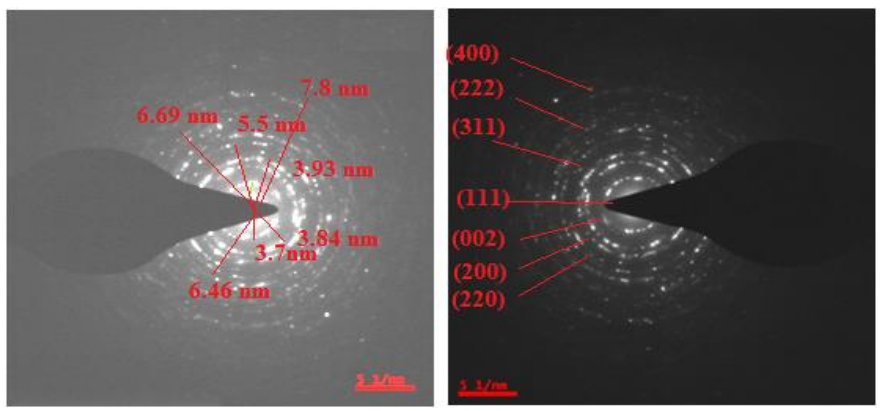

Fig. 5 SAED pattern for $\mathrm{ZrO}_{2}$ thick film sample

It was observed that $\mathrm{d}$ values calculated from XRD and TEM were well matched with d values of standard reported JCPDS data cards 17-0923, 036-0420, 81-1550 and 37-1484.

\subsubsection{Thin Film Analysis}

Fig. 6 (a) and (b) are the TEM images of the $\mathrm{ZrO}_{2}$ thin film sample and Fig. $6(\mathrm{c})$ is the HRTEM image of the same sample. Fig. 6(d) is the SAED image of the thin film sample. TEM images confirms the nanocrystalline nature of the films. The average particle size calculated from TEM image is found to be $34 \mathrm{~nm}$. Also, d spacing values estimated using XRD and TEM analysis and they are well match with standard data card.
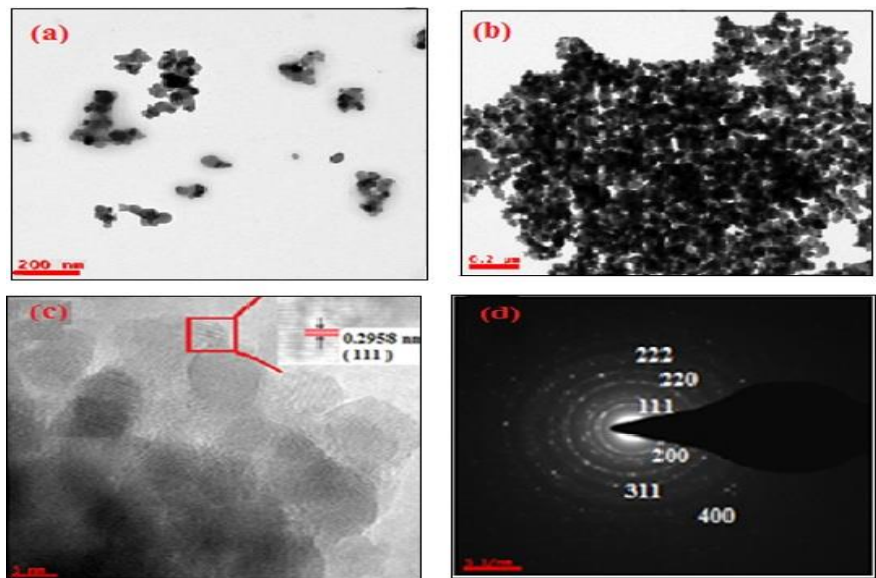

Fig. 6 (a-b) TEM images, (c) HRTEM image and (d) SAED pattern thin film sample 


\subsection{Optical Properties}

The variation of absorption with wavelength (nm) is shown in Figs. 7 (a) and (b). The absorbance of the film decreases gradually with increase in wavelength.

The optical band gap $\mathrm{E}_{\mathrm{g}}$ is calculated using the formula,

$$
\mathrm{E}_{\mathrm{g}}(\mathrm{eV})=\mathrm{hv}=\mathrm{hc}=\frac{\mathrm{hc}}{\lambda}=\frac{1240}{\lambda(\mathrm{nm})}
$$

where $\mathrm{h}$ is planks constant, $v$ is frequency, $\mathrm{c}$ is speed of light, and $\lambda$ is the wavelength in $\mathrm{nm}$ at interpolation of the linear portion of the curve, which determines the band gap in $\mathrm{eV}$.

The observed band gaps are 4.67 and $4.8 \mathrm{eV}$ for thick and thin film respectively. It is found that increase in band gap may be due to decrease in grain size [17-23].
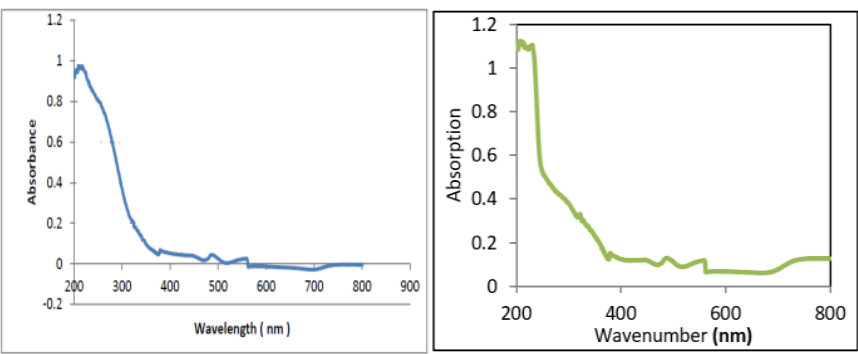

Fig. 7 (a-b) Absorption spectra of $\mathrm{ZrO}_{2}$ thick and thin films

\subsection{Comparative Reports from the Studied Analytical Techniques}

Table 2 concludes that thin films are suitable for different application since it provides significant properties of thin films.

Table 2 Comparative study of structural, morphological and optical band gap energy of $\mathrm{ZrO}_{2}$ thick and thin film

\begin{tabular}{llll}
\hline $\begin{array}{l}\text { Analytical } \\
\text { technique }\end{array}$ & Properties & Thick film & Thin film \\
\hline XRD & $\begin{array}{l}\text { Average } \\
\text { crystallite size } \\
\text { Average }\end{array}$ & $25 \mathrm{~nm}$ & $5.8 \mathrm{~nm}$ \\
GEM/FESEM & $\begin{array}{l}\text { Grain size } \\
\text { Average } \\
\text { TEM }\end{array}$ & $70-140 \mathrm{~nm}$ & $37 \mathrm{~nm}$ \\
UV-spectroscopy & $\begin{array}{l}\text { Particle size } \\
\text { Band gap }\end{array}$ & $4.67 \mathrm{eV}$ & $33 \mathrm{~nm}$ \\
Nature of film & Structure & Polycrystalline(Bulk) & Nanocrystalline \\
\hline
\end{tabular}

\section{Conclusion}

The $\mathrm{ZrO}_{2}$ powder can be prepared using $\mathrm{ZrOCl}_{2} .8 \mathrm{H}_{2} \mathrm{O}$ as starting material. Thick films of $\mathrm{ZrO}_{2}$ were prepared using screen printing techniques and thin films by spray pyrolysis techniques. XRD confirmed the identity of $\mathrm{ZrO}_{2}$ powder and thick films. Surface morphology studies from SEM and TEM analysis confirmed that grains are observed to be mixed shape of spherical and tetragonal nature. From the EDAX spectra it is confirmed that initially $\mathrm{ZrO}_{2}$ powder was nonstoichiometric and after firing it was found to be stoichiometric in nature. Optical band gap of films fired at different temperature was found as 4.67 and $4.8 \mathrm{eV}$.

\section{Acknowledgements}

The authors thanks to Principal, M.S.G. Arts, Science and Commerce College, Malegaon; Principal G.D.M. Arts, K.R.N. Commerce and M.D. Science College, Jamner College for providing laboratory facilities for this work.

\section{References}

[1] H. Omidvar, H.K. Pabandi, Effect of particle size $\mathrm{ZrO}_{2}$ in the nano and micrometer scale on wear behavior of the arbed, Int. J. Adv. Mech. Civil Eng. 3 (2016) 40-43.

[2] P. Chinna, S. Rao, T. Prasad, M. Harish, Evaluation of mechanical properties of $\mathrm{Al}-\mathrm{ZrO}_{2}$ metal matrix composite by using stir casting technique, Int. J. Sci. Res. Eng. Technol. 6 (2017) 377-381.

[3] T. Maekawa, J. Tamaki, N. Miura, N. Yamazoe, Sensing behavior of CuO loaded $\mathrm{SnO}_{2}$ element for $\mathrm{H}_{2} \mathrm{~S}$ detection, Chem. Lett. 575 (1991) 162-168.

[4] G. Sarala Devi, S. Manorama, V.J. Rao, High sensitivity and selectivity an $\mathrm{SnO}_{2}$ sensor to $\mathrm{H}_{2} \mathrm{~S}$ at around $100{ }^{\circ} \mathrm{C}$. Sens. Actuators B 28 (1995) 31-37.

[5] P. Mitra, A.K. Mukhopadhyay, $\mathrm{ZnO}$ thin film as methane sensor, Bull. Polish Acad. Sci. Tech. Sci. 55 (2007) 281-285.

[6] M.K. Hossain, S.C. Ghosh, Y. Boontongkong, C. Thanachaynont, J. Dutta, Growth of zinc oxide nanowire and nonobelts for gas sensing application, J. Meta. Nanocryst. Mat. 23 (2005) 27-30.

[7] N. Yamazoe, Review toward innovations of gas sensor technology, Sens. Actuators B 108 (2005) 2-14.

[8] C.N. Xu, J. Tamaki, N. Miura, N. Yamazoe, Grain size effects on gas sensitivity of porous $\mathrm{SnO}_{2}$-based elements, Sens. Actuators B 3 (1991) 147-155.

[9] E. Comini, G. Faglia, G. Sberveglieri, Z. Pan, Z.L. Wang, Stable and highly sensitive gas sensors based on semiconducting oxide nanobelts, Appl. Phys. Lett. 81 (2002) 1869-1871.

[10] D.A. Kumar, J.M. Shyla, F.P. Xavier, Synthesis and characterization of $\mathrm{TiO}_{2} / \mathrm{SiO}_{2}$ nanocomposites for solar cell applications, Appl. Nanosci. 2 (2012) 429-436.

[11] H. Setyawati, H. Darmokoesoemo, F. Rochman, A.J. Permana, Affordable dye sensitizer by waste, Mat. Renew. Sust. Ener. 6 (2017) 1-6.

[12] M.N. Rashed, A.A. El-Amin, Photocatalytic degradation of methyl orange in aqueous $\mathrm{TiO}_{2}$ under different solar irradiation sources, Int. J. Phys. Sci. 2 (2007) 073-081.

[13] S. Arunmetha, M. Vinoth, S.R. Srither, A. Karthik, M. Sridharpanday, et al., Study on production of silicon nanoparticles from quartz sand for hybrid solar cell applications, J. Elect. Mater. 47 (2018) 493-502.

[14] W. Chamsaard, S. Brundavanam, C.C. Fung, D. Fawcett, G. Poinern, Nanofluid types, their synthesis, properties and incorporation in direct solar thermal collectors: A review, Nanomater. 7 (2017) 1-31.

[15] A.H.S. Dehaghani, R. Daneshfar, How much would silica nanoparticles enhance the performance of low-salinity water fooding?, Petrol. Sci. 16 (2019) 591-605.

[16] K. Muller, E. Bugnicourt, M. Latorre, M. Jorda, Y.E. Sanz, et al., Review on the processing and properties of polymer nanocomposites and nanocoatings and their applications in the packaging, automotive and solar energy fields, Nanomater. 7 (2017) 1-47.

[17] S.B. Patil, R.H. Bari, Fast detection and highly $\mathrm{H}_{2} \mathrm{~S}$ sensing performance of chemically sprayed nanocomposites thin films, J. Inform. Comp. Sci. 9 (2019) 7-23

[18] S.B. Patil, R.H. Bari, Sprayed nanostructured $\mathrm{TiO}_{2}$ thin films and its application for gas sensor, J. Inform. Comp. Sci. 9 (2019) 33-45.

[19] R.H. Bari, S.B. Patil, S.B. Deshmukh, Ammonia sensing performance of Nanostructure CT doped $\mathrm{ZrO}_{2}$ thin films deposited by spray route, J. Nanosci. Tech. 2 (2016) 181-185.

[20] S.B. Deshmukh, Effect of calcination and firing temperature on structural morphological, compositional properties of $\mathrm{ZrO}_{2}$ thick films, Int. J. Chem. Phys. Sci. 7 (2015) 435-442.

[21] S.B. Deshmukh, R.H. Bari, Nanostructured $\mathrm{ZrO}_{2}$ thin films by spray pyrolysis technique for ammonia gas sensing application, International letters of Chemistry, Phys. Astron. 56 (2015) 120-130

[22] S.B. Deshmukh, R.H. Bari, Synthesis and Characterization of $\mathrm{CuO}$ doped $\mathrm{ZrO}_{2}$ hollow sphere for gas sensing application, Mater. Today: Proc. 3 (2016) 216223.

[23] S.B. Deshmukh, R.H. Bari, Acetone sensing performance of nanostructure cd doped $\mathrm{ZrO}_{2}$ spray pyrolyzed thin films, Sensor Lett. ASP 13 (2015) 934-939. 